\title{
Chronic osteo-articular changes in patients with sickle cell disease
}

\author{
Taciana Fernandes Araújo Ferreira ${ }^{1 *}$ (D), Ana Paula Teixeira dos Santos ${ }^{2}$, Alexandra Silva Leal ${ }^{3}$, \\ Gilberto de Araújo Pereira ${ }^{3}$, Sheila Soares Silva ${ }^{3}$ and Helio Moraes-Souza ${ }^{3}$
}

\begin{abstract}
Background: Sickle cell disease $(S C D)$ is an autosomal recessive genetic disease in which a mutation occurs in the $\beta$-globin chain gene, resulting in abnormal hemoglobin levels. In an environment with reduced oxygen concentration, red blood cells change their conformation, resulting in chronic hemolysis and consequent anemia and vaso-occlusive crises with injuries to several organs, with a significant impairment of the osteoarticular system. This study aimed to verify the chronic osteoarticular alterations and their association with clinical and laboratory characteristics of patients with SCD with a more severe phenotype $\left(S S\right.$ and $S \beta^{\circ}$ ), on a steady-state fasis.
\end{abstract}

Methods: Fifty-five patients were referred to a medical consultation with a specialized assessment of the locomotor system, followed by laboratory tests and radiographic examinations.

Results: In total, $74.5 \%$ patients had hemoglobinopathy SS; $67.3 \%$ were female; and $78.2 \%$ were non-whites. The mean patient age was 30.5 years. Most patients (61.8\%) reported up to three crises per year, with a predominance of high-intensity pain (65.5\%). Radiographic alterations were present in $80 \%$ patients. A total of 140 lesions were identified, most which were located in the spine, femur, and shoulders. Most lesions were osteonecrosis and osteoarthritis and were statistically associated with the non-use of hydroxyurea.

Conclusions: There was a high prevalence of chronic osteoarticular alterations, which was statistically associated only with the non-regular use of hydroxyurea.

Keywords: Osteonecrosis, Osteoarthritis, Osteopenia, Sickle cell disease, Hydroxyurea

\section{Introduction}

Hemoglobinopathies are a group of diseases of genetic origin in which mutations in the genes encoding hemoglobin $(\mathrm{Hb})$ can result in changes in their synthesis. Most of them comprise qualitative defects that result in the production of different $\mathrm{Hb}$ molecules with abnormal structure, resulting in sickle cell disease (SCD), and quantitative defects that affect the synthesis of globin chains, resulting thalassemias [1].

Hemoglobin S (HbS) is caused by a mutation in the $\beta$ chain gene due to the replacement of the amino acids

\footnotetext{
*Correspondence: taciferreira@yahoo.com.br

${ }^{1}$ Clinical Hospital of Federal University Triângulo Mineiro, Functional Units Rom, Av. Getúlio Guaritá, 130, B. Nossa Senhora da Abadia, CEP 38.025-440, Uberaba, MG, Brazil

Full list of author information is available at the end of the article
}

glutamate with valine at position 6 of chromosome 11 . Hemoglobinopathies in which at least one of the mutant hemoglobin is $\mathrm{HbS}$ are known as SCD. Hemoglobin S in homozygosis (HbSS), is called sickle cell anemia (SCA), which is the most severe form of SCD. HbS may also be associated with other abnormal hemoglobins, such as $\mathrm{HbC}, \mathrm{HbD}$, and $\beta$-thalassemia, leading to hemoglobinopathies $\mathrm{SC}, \mathrm{SD}, \mathrm{S} \beta^{0}$, and $\mathrm{S} \beta^{+}$, while the combination of $\mathrm{HbS}$ and $\mathrm{HbA}$ is called sickle cell trait, in which the carrier does not develop the disease [2]. The most severe SCD phenotypes are associated with the $S S$ and $S \beta^{0}$ genotypes, with similar clinical manifestations [3].

Since 1998 in Minas Gerais, Brazil, SCD is diagnosed at birth using the "little foot test," and children diagnosed with SCD are referred early for specialized followup.

(c) The Author(s). 2021 Open Access This article is licensed under a Creative Commons Attribution 4.0 International License, which permits use, sharing, adaptation, distribution and reproduction in any medium or format, as long as you give appropriate credit to the original author(s) and the source, provide a link to the Creative Commons licence, and indicate if changes were made. The images or other third party material in this article are included in the article's Creative Commons licence, unless indicated otherwise in a credit line to the material. If material is not included in the article's Creative Commons licence and your intended use is not permitted by statutory regulation or exceeds the permitted use, you will need to obtain permission directly from the copyright holder. To view a copy of this licence, visit http://creativecommons.org/licenses/by/4.0/. 
The clinical manifestations of SCD are due to two main phenomena-hemolysis and consequent chronic anemia as well as vaso-occlusion by red blood cells, followed by infarction in various organs and tissues. The vaso-occlusive phenomenon manifest acutely with severe pain crisis and chronically with lesions in various organs and tissues such as the lungs, heart, kidneys, liver, retina, skin, joints, and bones [4].

Osteoarticular manifestations occur in different forms of SCD and are more severe in SCA [5]. Acute lesions include hand-foot syndrome (sickle cell dactylitis), pain crises, osteomyelitis, infectious and inflammatory arthritis, stress fractures, bone infarctions, vertebral collapse secondary to osteonecrosis (ON) with a typical "fish mouth" appearance, dental changes, and orbital compression [6]. Chronic changes include avascular necrosis or ON, vertebral collapse due to low bone mass (fragility fractures), inflammatory chronic arthritis, osteoarthritis (OA), bone marrow hyperplasia triggering morphological changes and growth disorders, osteopenia, and osteoporosis [7].

Acute osteoarticular changes determine a severe clinical picture with generally intense events such as sickle cell dactylitis. In contrast, chronic changes can develop silently or after an acute event, determining functional limitations and symptoms of varying degrees of intensity. They are often underdiagnosed, although with an important impact on the morbidity and mortality of these patients, requiring accurate knowledge of the different manifestations to provide correct diagnosis and appropriate treatment.

Therapeutic approaches capable of modifying the natural history of SCD include hypertransfusion, use of hydroxyurea (HU), and hematopoietic stem cell transplantation (HSCT). Currently, HU is the only drug capable of altering the natural history of SCD. Its use in Brazil is guided by hematological clinical indications according to the Clinical Protocol and Therapeutic Guidelines of the Ministry of Health [8].

In addition to increasing the fetal hemoglobin (HbF) concentration, $\mathrm{HU}$ increases the total concentration of $\mathrm{Hb}$ and causes a reduction in the number of neutrophils, monocytes, and reticulocytes. Furthermore, HU affects the red blood-endothelium interaction and acts as a nitric oxide donor. Although $\mathrm{HU}$ treatment is effective, there is variability in patients' response to HU. In 10$25 \%$ cases, treatment with HU is not effective, perhaps due to genetic variation, bone marrow exhaustion, variation in drug metabolism, and possibly lack of adherence to treatment [9].

\section{Objective}

This study aimed to verify chronic osteoarticular alterations and their association with clinical and laboratory characteristic of patients with SCD of the more severe phenotype ( $\mathrm{SS}$ and $\mathrm{S} \beta^{0}$ ) who were followed up at Regional Blood Center of Uberaba (RBCU) and Clinical Hospital of Federal University of Triângulo Mineiro (CH-FUTM) on a steady-state fasis.

\section{Methods}

A cross-sectional study was conducted from May 2017 to January 2018 at RBCU. The sample size was maximized. All eligible patients who attended routine consultations were invited to participate and were included in the study according to their consent and compliance with the evaluation protocols. Of the 67 eligible patients (SS and $\mathrm{S} \beta^{0}$, 14 years or older, non-pregnant women), 12 did not accept participation or did not complete the evaluation protocol, resulting in 55 participants (nonprobabilistic sampling).

After signing the free and informed consent term and/ or the informed consent form, the patients were referred for medical consultation with a rheumatologist, consisting of a clinical interview and physical examination with specialized assessment of the locomotor system, followed by laboratory and radiographic examinations. Data on patient's past history were collected from the medical records provided by the Medical File Service of RBCU and CH-FUTM.

Regarding age, the participants were divided into two groups according to the United Nations (UN) classification [10], with individuals aged 14-24 years being considered young patients and individuals aged $>25$ years being considered adult patients. The skin color was classified as white, brown, or black based on self-reported data. However, for analysis, white and brown patients were included in the same subgroup since all non-black patients reported no black ancestry.

Prolonged use of $\mathrm{HU}$ was defined as use for at least 1 year without interruption.

The participants were asked about the average number of painful crises presented per year and classified into mild, moderate, or high groups according to the Pain Analog Scale scores [11].

The laboratory tests included those for ferritin, reticulocytes, C-reactive protein (CRP), and lactic dehydrogenase (LDH). We retrieved the values of fetal hemoglobin and basal hemoglobin $(\mathrm{BHb})$ from the medical records.

For radiographic screening, the following were examined: the hand and wrist, shoulders, cervical, thoracic and lumbar spine, pelvis, and skull. When changes in physical examination were observed, the knees, ankle, feet, and long bones were examined.

The data were arranged in an Excel spreadsheet, from which descriptive statistical analysis and association were performed using the chi-square test. Statistical Package for Social Science for Windows (SPSS) version 22.1.1.1 
was used for statistical analysis. The level of statistical significance set at $5 \%(p<0.05)$.

\section{Results}

Among the 55 individuals, 41 (74.5\%) had SS hemoglobinopathy, $14 \quad(25.5 \%)$ had $S \beta^{0}$ hemoglobinopathy, 37 (67.3\%) were female, 27 (49.1\%) were black, and 28 (50.9\%) were non-black. The mean ( \pm standard deviation $[\mathrm{SD}])$ patient age was $30.5( \pm 11.5)$ years (range: $15-54$ years). In total, 21 patients were categorized as young patients (age: $14-24$ years; $38.2 \%$ ), and 34 patients were categorized as adult patients (age: $\geq 25$ years; $61,8 \%$ ). Thirty-five $(63.6 \%)$ participants used HU for at least 1 year uninterruptedly.

The mean $( \pm \mathrm{SD})$ values of the various laboratory parameters evaluated were as follows: FHb, $11.3( \pm 6.7) \mathrm{g} /$ $\mathrm{dL} ; \mathrm{BHb}, 7.9( \pm 1.2) \mathrm{g} / \mathrm{dL}$; ferritin, $743.2( \pm 1159.7) \mathrm{ng} /$ $\mathrm{mL}$; reticulocytes, $6.6 \%( \pm 2.9 \%) ; \mathrm{CRP}, 0.7( \pm 0.9) \mathrm{mg} / \mathrm{L}$; and LDH, $472.9( \pm 166.8) \mathrm{U} / \mathrm{L}$.

The distribution of participants according to the frequency and intensity of pain crises is shown in Table 1. We observed that most participants reported up to three attacks per year (61.8\%), and the pain was high in $65.8 \%$ painful episodes.

Regarding radiographic alterations, 140 lesions were identified, most of which occurred in the spine (62.1\%), followed by the femur (16.4\%) and the shoulders (7.1\%). The most frequent alteration was $\mathrm{ON}$ (55\%), followed by OA (21.4\%) (Table 2). ON was identified in $29.1 \%$ patients, OA was identified in 25.4\% patients. Most patients had several lesions simultaneously (Table 2).

Regarding the number of radiographic lesions per patient, most patients had $1-4$ lesions $(63.6 \%)$, with a variation of zero $(20.0 \%)$ to nine $(1.8 \%)$, with mean and SD of 2.61 and \pm 2.22 , respectively.

The association between laboratory and clinical parameters and the number of radiographic lesions was not statistically significant, except for the use of $\mathrm{HU}$ $(p=0.0038)$ (Table 3).

Among people with $\geq 5$ injuries, most were women (21.6\%), non-black (17.9\%), adults $(20.6 \%)$, with $\geq 4$ attacks in 1 year (19.9\%) and with high pain intensity

Table 1 Distribution of the participants according to the frequency and intensity of painful crises

\begin{tabular}{lll}
\hline Variables & N & $\%$ \\
\hline Number of crises per year & & \\
$0-3$ & 34 & 61.8 \\
$\geq 4$ & 21 & 38.2 \\
Intensity of pain in crises & & \\
Mild and moderate & 19 & 34.5 \\
High & 36 & 65.5 \\
\hline
\end{tabular}

Table 2 Distribution of radiographic lesions according to location and type of alteration

\begin{tabular}{|c|c|c|}
\hline Radiographic Changes & $\mathbf{N}$ & $\%$ \\
\hline \multicolumn{3}{|l|}{ Location of lesions } \\
\hline Spine & 74 & 52.8 \\
\hline Proximal femur/hip & 23 & 16.4 \\
\hline Shoulders/humerus & 10 & 7.1 \\
\hline Skull & 7 & 5.0 \\
\hline Hands and wrists & 4 & 2.8 \\
\hline Other ${ }^{a}$ & 22 & 15.7 \\
\hline Total & 140 & 100.0 \\
\hline \multicolumn{3}{|l|}{ Types of alterations } \\
\hline Osteonecrosis & 77 & 55.0 \\
\hline Osteoarthritis & 30 & 21.4 \\
\hline Other SCD-related changes ${ }^{b}$ & 17 & 12.2 \\
\hline Non-specific changes ${ }^{c}$ & 16 & 11.4 \\
\hline Total & 140 & 100.0 \\
\hline
\end{tabular}

Other $^{\mathrm{a}}$ : tibia, fibula, knees, distal femur, ulna, ankle, and feet

Other changes related to $\mathrm{SCD}^{\mathrm{b}}$ : thickening of the diploe, sequelae of osteomyelitis, pyogenic arthritis, dactylitis, and discitis, consolidated fractures Non-specific changes ${ }^{c}$ : Non-specific lytic lesions, flexion deformity, clinodactyly, tendinopathy, kyphosis, scoliosis, transition vertebra, omovertebral bone, trigone bone, and equine foot

(16.7\%); however, the difference was not statistically significant (Table 3).

Of the 35 individuals who used HU regularly for $>1$ year, only $8.6 \%$ had $\geq 5$ injuries, while of the 20 individuals who did not use it regularly, $30.0 \%$ had $\geq 5$ injuries $(p=0.0038)$ (Table 3).

\section{Discussion}

The patients' profiles in this study are compatible with those described in the literature, with a predominance of homozygous disease (SS), female sex, non-white individuals, and young individuals $[9,12,13]$. However, most patients in this study reported a low frequency of pain crises, which is different from that reported in previous studies $[9,14,15]$.

Platt and colleagues has suggested that people with SCD with $\mathrm{HbF}$ values $>8 \%$ have a higher survival rate [11], which may indicate a better prognosis for our patients, but with cumulative damage to the osteoarticular system.

The bone is the second most affected organ by SCD after the spleen [16]. We found 140 osteoarticular lesions in our cohort (mean: 2.61/participant). However, 20\% participants did not present any radiographic lesions.

Previous studies have evaluated osteoarticular involvement in patients with SCD in the acute phase. However, our study evaluated lesions in patients on a steady-state fasis, which explains the low incidence of infectious and inflammatory changes, which were highly prevalent in past studies [17-19], and a high incidence of OA and ON. 
Table 3 Evaluation of the number of lesions according to epidemiological and clinical characteristics

\begin{tabular}{|c|c|c|c|c|c|c|c|c|c|}
\hline \multicolumn{10}{|l|}{ Number of injuries } \\
\hline \multirow[t]{2}{*}{ Clinical data } & \multicolumn{2}{|l|}{0} & \multicolumn{2}{|c|}{$1-4$} & \multicolumn{2}{|c|}{$\geq 5$} & \multicolumn{2}{|c|}{ Total } & \multirow[t]{2}{*}{$p$ value $^{*}$} \\
\hline & $\mathrm{N}$ & $\%$ & $\mathrm{~N}$ & $\%$ & $\mathrm{~N}$ & $\%$ & $\mathbf{N}$ & $\%$ & \\
\hline \multicolumn{10}{|l|}{ Sex } \\
\hline Male & 6 & 33.3 & 11 & 61.1 & 1 & 5.6 & 18 & 100 & 0.1156 \\
\hline Female & 5 & 13.6 & 24 & 64.8 & 8 & 21.6 & 37 & 100 & \\
\hline Total & 11 & 20.0 & 35 & 63.6 & 9 & 16.4 & 55 & 100 & \\
\hline \multicolumn{10}{|l|}{ Skin color } \\
\hline Black & 4 & 14.8 & 19 & 70.4 & 4 & 14.8 & 27 & 100 & 0.5575 \\
\hline Non-black & 7 & 25.0 & 16 & 57.1 & 5 & 17.9 & 28 & 100 & \\
\hline Total & 11 & 20.0 & 35 & 63.6 & 9 & 16.4 & 55 & 100 & \\
\hline \multicolumn{10}{|l|}{ Age } \\
\hline Young & 7 & 33.3 & 12 & 57.1 & 2 & 9.6 & 21 & 100 & 0.1215 \\
\hline Adults & 4 & 11.7 & 23 & 67.6 & 7 & 20.6 & 34 & 100 & \\
\hline Total & 11 & 20.0 & 35 & 63.6 & 9 & 16.4 & 55 & 100 & \\
\hline \multicolumn{10}{|c|}{ Number of crises per year } \\
\hline $0-3$ & 5 & 14.7 & 24 & 70.6 & 5 & 14.7 & 34 & 100 & 0.3546 \\
\hline$\geq 4$ & 6 & 28.6 & 11 & 52.4 & 4 & 19.0 & 21 & 100 & \\
\hline Total & 11 & 20.0 & 35 & 63.6 & 9 & 16.4 & 55 & 100 & \\
\hline \multicolumn{10}{|l|}{ Intensity of crises } \\
\hline Mild and moderate & 4 & 21.1 & 12 & 63.2 & 3 & 15.8 & 19 & 100 & 0.9886 \\
\hline High & 7 & 19.4 & 23 & 63.9 & 6 & 16.7 & 36 & 100 & \\
\hline Total & 11 & 20.0 & 35 & 63.6 & 9 & 16.4 & 55 & 100 & \\
\hline \multicolumn{10}{|l|}{ HU use $\geq 1$ years } \\
\hline Yes & 4 & 11.4 & 28 & 72.8 & 3 & 8.6 & 35 & 100 & $0.0038^{* *}$ \\
\hline No & 7 & 35.0 & 7 & 35.0 & 6 & 30.0 & 20 & 100 & \\
\hline Total & 11 & 20.0 & 35 & 63.6 & 9 & 16.4 & 55 & 100 & \\
\hline
\end{tabular}

The main sites of bone involvement were the spine, followed by the femur and the shoulders and the most frequent changes were $\mathrm{ON}$, followed by $\mathrm{OA}$, as classically described [6].

The prevalence of $\mathrm{ON}$ in people with SCA ranges from 3.2 to $26.7 \%$ [19-22]. In our study, this complication affected approximately one-third of the patients. However, like other studies, we observed that the prevalence of $\mathrm{ON}$ increases with age, which may be a consequence of recurrent episodes of bone infarctions. Globally, SCD is probably the most common cause of avascular necrosis that most commonly affecting the femoral and humeral heads [23].

Patients with SCD may develop OA, usually secondary to $\mathrm{ON}$, which progresses to $\mathrm{OA}$ in $86 \%$ patients when not properly treated $[24,25]$. These data justify the high prevalence of this type of lesion verified in the evaluation of patients in an outpatient setting on a steady-state basis.
The occurrence of radiographic alterations did not present a statistically significant association with sex, skin, age, number, and intensity of pain attacks; however, we observed that despite the higher percentage of individuals without radiographic lesions in the young group, painful crises were of high intensity in this group. In the group of people with $\geq 5$ injuries, the majority were adults and females. Radiographic changes are secondary to injuries suffered by patients throughout their lives, which may explain the higher incidence of young patients among those without identifiable radiographic injuries and adults with a higher incidence of radiographic damage.

Individuals who regularly used HU had a lower incidence of multiple lesions than those who did not use it, statistically significant result.

Treatment with HU is associated with a significant reduction in the incidence of hospitalization, acute chest crisis, stroke, and vaso-occlusive crises, however, the impact of the use of this drug on the prevention and treatment of chronic osteoarticular lesions needs further investigation.

There is only one study published thus far regarding the osteoarticular alterations of SCD, which has cited high-dose HU significantly reduced the incidence of $\mathrm{ON}$ in white and non-white patients aged $>18$ years with $3 S$ / $ß S$ and $ß S / \aleph^{+}$treated for 10 years [26].

A review article on the role of HU in SCD describes the importance of this medication in reducing the morbidity and mortality in these individuals [27]. Because of the effects of $\mathrm{HU}$ in reducing the sickling of red blood cells, elevating $\mathrm{HbF}$, reducing oxidative stress and vasoocclusive crisis consequently, we infer that $\mathrm{HU}$ also has a positive impact on osteoarticular lesions, as reinforced by the findings of the present study.

SCD is a disease that has a great impact on the osteoarticular system of affected patients, which can lead to functional limitations and low quality of life, requiring special care by a health team. Until new drugs are available, HU should always be considered an important therapeutic option in patients with SCD.

The main limitations of the study were the small sample size, its heterogeneity, the limitation in the recording of data in medical records, and the difficulty in performing some tests in our hospital.

Future studies with a larger sample, including other hemoglobinopathies, control group and nuclear magnetic resonance exams may bring further clarifications on this topic.

\section{Conclusions}

In patients whith SCD SS e $S \beta^{0}$ followed at RBCU and $\mathrm{CH}$-FUTM, we observed a high prevalence of chronic osteoarticular alterations, being statistically associated, as a protective measure, only with regular use of HU. 


\section{Acknowledgements}

Not applicable.

\section{Authors' contributions}

Calculations and nutritional assessments: Alexandra Silva Leal; Conducting and reporting the imaging exams: Ana Paula Teixeira dos Santos; Conception and design of the research: Taciana Fernandes Araújo Ferreira, Gilberto de Araújo Pereira, Sheila Soares Silva, Helio Moraes-Souza. The author(s) read and approved the final manuscript.

\section{Authors' information}

Taciana Fernandes Araújo Ferreira: Master's student of the Master's Program in Health Sciences of the Federal University of Triângulo Mineiro, Uberaba, MG, Brazil.

Ana Paula Teixeira dos Santos: Resident Physician specialized in Radiology and Diagnostic Imaging at the Clinical Hospital of Federal University of Triângulo Mineiro, Uberaba, MG, Brazil.

Alexandra Silva Leal: PhD in Health Sciences from the Federal University of Triângulo Mineiro, Uberaba, MG, Brazil.

Gilberto de Araújo Pereira: Associate Professor at the Institute of Health Sciences, Professor of the Professional Master's Graduate Programs in Technological Innovation and Public Management at the Federal University of Triângulo Mineiro, Uberaba, MG, Brazil.

Sheila Soares Silva: Associate Professor of the Discipline of Hematology and Hemotherapy, Federal University of Triângulo Mineiro, Uberaba, MG, Brazil. Helio Moraes-Souza: Full Professor of the Discipline of Hematology and Hemotherapy, Federal University of Triângulo Mineiro, Uberaba, MG, Brazil.

\section{Funding}

This work did not receive funding for its performance.

\section{Availability of data and materials}

The datasets generated and/or analyzed during the current study are not publicly available due due to the confidentiality of participants' data but are available from the corresponding author on reasonable request.

\section{Ethics approval and consent to participate}

The work was approved by the Institutional Research Ethics Committee. Participants signed the Informed Consent Form to participate in the research.

\section{Consent for publication}

All authors give consent for publication of this work.

\section{Competing interests}

None of the authors have conflicts of interest in relation to the topics covered in this article.

\section{Author details}

${ }^{1}$ Clinical Hospital of Federal University Triângulo Mineiro, Functional Units Rom, Av. Getúlio Guaritá, 130, B. Nossa Senhora da Abadia, CEP 38.025-440, Uberaba, MG, Brazil. ${ }^{2}$ Clinical Hospital of Federal University Triângulo Mineiro, Uberaba, MG, Brazil. ${ }^{3}$ Federal University of Triângulo Mineiro, Uberaba, MG, Brazil.

Received: 18 September 2020 Accepted: 10 February 2021

\section{Published online: 19 February 2021}

\section{References}

1. Batista GA, Santos NA, Marquetti VB, Mota WB, Silvério ASD. Hemoglobinopatias: investigação em sangue periférico de acadêmicos de uma universidade de Alfenas - MG. Rev Med (São Paulo). 2020;99(3):246-50.

2. Brasil. Ministério da Saúde. Agência Nacional de Vigilância Sanitária. Manual de diagnóstico e tratamento de doenças falciformes. 1st ed. Brasília; 2002. p. 142

3. Shayeb AM, Smeltzer MP, Kaste SC, Brown A, Estepp JH, Nottage KA. Vasoocclusive crisis as a predictor of symptomatic avascular necrosis in children with sickle cell disease. Pediatric Blood Cancer. 2018;65(12):e27435.

4. Reed W, Vichinsky EP. New considerations in the treatment of sickle cell disease. Annu Rev Med. 1998:49:461-74.
5. Souza HM, Valize PCB, Souza LRMF. Manifestações reumáticas das hemoglobinopatias. In: Cecin HA, Ximenes AC, editors. Tratado Brasileiro de Reumatologia. São Paulo: Atheneu; 2015.

6. Almeida A, Roberts I. Bone involvement in sickle cell disease. $\mathrm{Br} J$ Haematol. 2005;129(4):482-90.

7. Claster S, Vichinsky EP. Managing sickle cell disease. Br Med J. 2003. 327(7424):1151-5.

8. Ministério da Saúde. Secretaria de Atenção à Saúde Secretaria de Ciência, Tecnologia e Insumos Estratégicos. Protocolo Clínico e Diretrizes Terapêuticas - Doença Falciforme 2018.

9. Fainstein RSQ, Ramos MC, Mendonça D, Gesteira MF. Uso de hidroxiuréia no tratamento da doença falciforme. Rev Baiana Pediat. 2006;2(1):46-55.

10. Eisenstein E. Adolescência: definições, conceitos e critérios. Adolesc Saud. 2005;2(2):6-7

11. Lobo C, Marra VN, Silva RMG. Crises dolorosas na doença falciforme. Rev Bras Hematol Hemoter. 2007:29(3):247-58.

12. Amaral JL, Almeida NA, Santos OS, Oliveira PP, Lanza FM. Sociodemographic, economic and health profile of adults with sickle-cell disease. Rev Rene. 2015;16(3):296-305.

13. Platt OS, Bamblia DJ, Rosse WF, Milner PF, Castro O, Steinberg MH, et al. Mortality in sickle cell disease - life expectancy and risk factors for early death. N Engl J Med. 1994;23(330):1639-44.

14. Cruz SV, Martelli DRB, Araújo MX, Leite BGL, Rodrigues LAM, Martelli JH. Avaliação da qualidade de vida em pacientes adultos com anemia falciforme no norte de Minas Gerais - Brasil. Rev Med Minas Gerais. 2016; 26(suppl. 5):S23-30.

15. Furtado NA, Motta J, Santos MDD. Estudo do perfil dos pacientes portadores de Síndromes Falciformes acompanhados no Serviço de Hematologia do Centro Estadual de Hemoterapia e Hematologia do Espírito Santo (HEMOES). Rev Bras Pesq Saúde. 2014;16(4):105-12.

16. Aleluia IP. Ocorrência de osteonecrose da cabeça femoral em pacientes com doença falciforme: um revisão sistemática. Trabalho de Conclusão de Curso (Medicina) - Universidade Federal da Bahia, Salvador, 2014

17. Bennett OM, Namnyak SS. Bone and joint manifestations of sickle cell anaemia. J Bone Joint Surg Br. 1990;72(3):494-9.

18. Sachan AA, Lakhkar BN, Lakhkar BB, Sachan S. Is MRI necessary for skeletal evaluation in sickle cell disease. J Clin Diagn Res. 2015;9(6):TC08-12.

19. Balogun RA, Obalum DC, Giwa SO, Adekoya-Cole TO, Ogo CN, Enweluzo GO. Spectrum of musculo-skeletal disorders in sickle cell disease in Lagos, Nigeria. J Orthop Surg Res. 2010;5:2.

20. Akinyoola AL, Adediran IA, Asaleye CM. Avascular necrosis of the femoral head in sickle cell disease in Nigeria: a retrospective study. Niger Postgrad Med J. 2007:14(3):217-20.

21. Hernigou P, Habibi A, Bachir D, Galacteros F. The natural history of asymptomatic osteonecrosis of the femoral head in adults with sickle cell disease. J Bone Joint Surg Am. 2006:88(12):2565-72.

22. Iwegbu CG, Fleming AF. Avascular necrosis of the femoral head in sickle-cel disease. A series from the Guinea Savannah of Nigeria. J Bone Joint Surg Br. 1985;67(1):29-32.

23. Hughes M, Akram Q, Rees DC, Jones AKP. Haemoglobinopathies and the rheumatologist. Rheumatology (Oxford). 2016;55(12):2109-18.

24. Mont MA, Zywiel MG, Marker DR, McGrath MS. Delanois RE the natural history of untreated asymptomatic osteonecrosis of the femoral head: a systematic literature review. J Bone Joint Surg Am. 2010;92(12):2165-70.

25. Alonge TO, Shokunbi WA. The choice of arthroplasty for secondary osteoarthritis of the hip joint following avascular necrosis of the femoral head in sicklers. J Natl Med Assoc. 2004:96(5):678-81.

26. Rigano P, Franceschi L, Sainati L, Piga A, Piel FB, Capellini MD, Fidone C, Masera N, Palazzi G, Gianesin B, Forni GL. Italian Multicenter Study of Hydroxyurea in Sickle Cell Anemia Investigators. Real-life experience with hydroxyurea in sickle cell disease: a multicenter study in a cohort of patients with heterogeneous descent. Blood Cells Mol Dis. 2018;69:82-9.

27. Souza EQ, Sales AA, CVS S, Andrade SM, Lucio Neto MP, Oliveira EH. Uso da hidroxiuréia na anemia falciforme: uma revisão da literatura. Res, Soc Dev. 2020:9(2):102922058

\section{Publisher's Note}

Springer Nature remains neutral with regard to jurisdictional claims in published maps and institutional affiliations. 